\title{
COMPARING VITAMIN D STATUS IN CENTRAL ASIA AND NORTHERN EUROPE
}

Received: Sept 10, 2019

Accepted: Sept 19, 2019

William B. Grant ${ }^{\mathbf{1}^{*}}$ https://orcid.org/0000-0002-1439-3285

1Sunlight, Nutrition, and Health Research Center, San Francisco, USA

\section{*Corresponding author:}

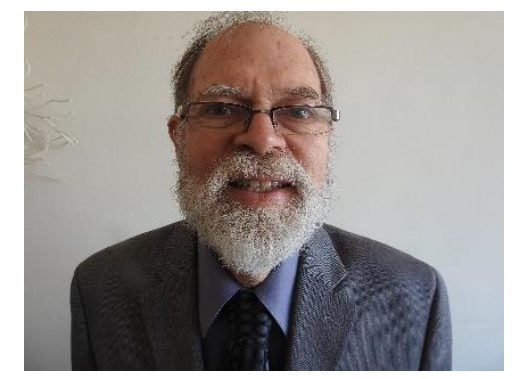

William B. Grant, Ph.D. Director, Sunlight, Nutrition, and Health Research Center, P.O. Box 641603, San

Francisco, CA 94164-1603, USA;

Twitter handle: @wbgrant2; E-mail: wbgrant@infionline.net

\begin{abstract}
Over the past two decades, the understanding of the roles of vitamin D has expanded to include many nonskeletal effects such as reduced risk of acute respiratory tract infections, autoimmune diseases, cancer, cardiovascular disease, diabetes mellitus, neurological diseases, and adverse pregnancy and birth outcomes. The role of vitamin $D$ for optimal health is well known in Western developed countries but less so in Central Asian countries. This narrative review compares the status of vitamin D between Central Asian countries and Northern European countries. The analysis also summarizes the evidence for the beneficial effects of vitamin $\mathrm{D}$ and recommendations for Central Asian countries.
\end{abstract}

Keywords: Vitamin D, Central Asia, Europe, Hypothesis How to cite: Grant W. B. Comparing vitamin D status in Central Asia and Northern Europe. Cent Asian J Med Hypotheses Ethics 2020;1(1):33-42. https://doi.org/10.47316/cajmhe.2020.1.1.05

\section{INTRODUCTION}

In the past two decades, the understanding of the roles of vitamin $D$ has expanded beyond the classical role of regulating calcium-phosphorus homeostasis and controlling bone metabolism. Evidence continues to mount that vitamin $D$ has many other functions. It reduces risk of musculoskeletal disorders (muscle weakness, falls, fractures), infectious diseases, autoimmune diseases, cardiovascular disease, type 1 and type 2 diabetes mellitus, several cancers, neurocognitive dysfunction and mental illness, as well as infertility and adverse pregnancy and birth outcomes [1,2]. The benefits of vitamin $D$ are generally appreciated in Europe and the United States but relatively unappreciated in Central Asia (CA). This paper strives to determine the health outcomes in CA that would benefit from increasing vitamin D status, 


\section{Central Asian Journal of Medical Hypotheses and Ethics| \\ 2020; Vol 1}

present the evidence regarding vitamin $\mathrm{D}$ for those outcomes, and recommend action for future research. Data on vitamin $D$ status and health outcomes for three northern European (NE) countries are included for comparison.

In this work, health outcomes considered are largely related to mortality rates. Mortality rate data were obtained from the World Health Organization.

To gain an understanding of the interest in vitamin $D$ in CA and NE countries, pubmed.gov and Scopus for CA were searched, using the terms "vitamin D" and "25-hydroxyvitamin D" and the name of each country. To find evidence that better vitamin $D$ status improves various health outcomes, both pubmed.gov and scholar.google.com were searched, using "vitamin D" and "25-hydroxyvitamin D" and the name of the health outcome.

\section{DATA FOR COUNTRIES IN CENTRAL ASIA AND NORTHERN EUROPE}

Table 1 gives the latitude and longitude of the capital cities of each country, along with the population, life expectancy and healthy life expectancy at birth, infant mortality rate, and chronic disease mortality rate for people aged 30 70 years [3]. Life expectancy and healthy life expectancy at birth is about 10 years shorter in CA than in $\mathrm{NE}$, infant mortality rates are much higher, and chronic disease mortality rates are about three times those in NE.

Table 1. Country data, 2017 [3]

\begin{tabular}{|l|l|l|c|l|l|c|c|}
\hline Country & Capital & $\begin{array}{l}\text { Latitude }\left({ }^{\circ} \mathrm{N}\right), \\
\text { Longitude } \\
\left({ }^{\circ} \mathrm{E}\right)\end{array}$ & $\begin{array}{l}\text { Population } \\
\text { (millions) }\end{array}$ & $\begin{array}{l}\text { LE } \\
\text { Birth } \\
(\mathrm{yrs})\end{array}$ & $\begin{array}{l}\text { HLE } \\
\text { Birth } \\
(\mathrm{yrs})\end{array}$ & $\begin{array}{l}\text { Neonatal } \\
\text { Mortality } \\
\text { Rate per } \\
1000\end{array}$ & $\begin{array}{l}\text { Chronic disease } \\
\text { Mortality rate, } \\
2015, \\
30-70 \text { yrs (\%) }\end{array}$ \\
\hline Afghanistan & Kabul & $34.56,69.21$ & 34.7 & 62.7 & 53.0 & 40.0 & 29.8 \\
\hline Kazakhstan & Nur-Sultan & $51.16,71.47$ & 18.0 & 71.1 & 63.4 & 5.9 & 26.8 \\
\hline Kyrgyzstan & Bishkek & $42.87,74.57$ & 6.0 & 71.4 & 63.5 & 11.8 & 24.9 \\
\hline Mongolia & Ulaanbaatar & $\begin{array}{l}47.89, \\
106.91\end{array}$ & 3.0 & 69.8 & 61.9 & 9.7 & 30.2 \\
\hline Tajikistan & Dushanbe & $38.36,68.79$ & 8.7 & 70.8 & 63.5 & 19.9 & 25.3 \\
\hline Turkmenistan & Ashgabat & $37.96,58.33$ & $5.7 ?$ & 68.2 & 61.4 & 22.3 & 29.5 \\
\hline Uzbekistan & Tashkent & $41.30,69.24$ & 29.9 & 69.4 & 62.4 & 20.4 & 31.0 \\
\hline Finland & Helsinki & $60.17,24.94$ & 5.5 & 81.4 & 71.7 & 1.2 & 10.2 \\
\hline Norway & Oslo & $59.91,10.75$ & 5.3 & 82.5 & 73.0 & 1.5 & 9.2 \\
\hline Sweden & Stockholm & $59.33,10.07$ & 9.8 & 82.4 & 72.4 & 1.6 & 9.1 \\
\hline
\end{tabular}

HLE: healthy life expectancy; LE: life expectancy

Table 2 gives age-adjusted mortality rates for males and females for the chronic diseases with the highest mortality rates for CA and NE countries [4].
Although cancer mortality rates are similar between $\mathrm{CA}$ and $\mathrm{NE}$, diabetes mellitus mortality rates are much higher in several CA countries. 


\section{Central Asian Journal of Medical Hypotheses and Ethics| \\ 2020; Vol 1}

Cardiovascular disease rates, including both ischemic heart disease (IHD) and stroke, are about five times higher. Chronic obstructive pulmonary disease rates are about twice as high; cirrhosis of the liver rates are more than 10 times higher than in Norway and Sweden; and kidney disease rates are about six times higher.

Table 2. Mortality rate data by country for various causes, 2015 [4]

\begin{tabular}{|l|r|r|r|r|r|r|r|r|r|r|}
\hline Country & $\begin{array}{c}\text { Quality } \\
\text { of } \\
\text { Data }\end{array}$ & Cancer & $\begin{array}{l}\text { Diab } \\
\text { etes }\end{array}$ & $\begin{array}{l}\text { Neuro } \\
\text { logical }\end{array}$ & CVD & IHD & Stroke & COPD & Cirrhosis & $\begin{array}{l}\text { Kidney } \\
\text { Disease }\end{array}$ \\
\hline Afghanistan & P & 119.5 & 60.4 & 39.0 & 459.6 & 287.0 & 137.9 & 40.8 & 17.9 & 43.3 \\
\hline Kazakhstan & Y & 151.2 & 8.4 & 27.8 & 481.4 & 311.3 & 125.2 & 37.7 & 49.9 & 11.2 \\
\hline Kyrgyzstan & G & 100.3 & 9.6 & 8.0 & 528.2 & 365.2 & 133.1 & 35.5 & 42.8 & 12.3 \\
\hline Mongolia & T & $209.6^{*}$ & 4.6 & 25.1 & 449.0 & 249.2 & 168.1 & 13.2 & 57.4 & 15.3 \\
\hline Tajikistan & T & 86.5 & 17.7 & 28.1 & 465.2 & 292.1 & 143.7 & 37.3 & 25.2 & 9.6 \\
\hline Turkmenistan & T & 110.4 & 18.3 & 27.3 & 560.6 & 385.1 & 137.5 & 11.4 & 52.9 & 24.1 \\
\hline Uzbekistan & G & 59.9 & 27.0 & 9.0 & 502.0 & 334.1 & 86.5 & 9.1 & 29.3 & 23.3 \\
\hline & & & & & & & & & & \\
\hline Finland & G & 99.7 & 4.1 & 60.0 & 128.6 & 71.8 & 28.1 & 9.4 & 12.3 & 2.6 \\
\hline Norway & G & 114.1 & 5.7 & 34.6 & 93.3 & 48.5 & 21.3 & 22.7 & 2.7 & 3.7 \\
\hline Sweden & G & 106.8 & 8.3 & 35.4 & 113.1 & 61.3 & 22.4 & 15.2 & 4.4 & 3.6 \\
\hline
\end{tabular}

Age-standardized rate per 100,000 population by cause and WHO member state (2015) (1812GHE2016_Death-rates-country

*Liver cancer rate, 92.5; COPD, chronic obstructive pulmonary disease; CVD, cardiovascular disease; IHD, ischemic heart disease; quality of data: $G$, high; $P$, death registration data unavailable; $T$, severe quality issues; Y, moderate.

One reason that $25(\mathrm{OH}) \mathrm{D}$ concentrations are higher in NE than in CA is that more fatty ocean fish is consumed in NE [5]. Another reason is that summer temperatures in CA are so hot that people probably do not spend much time in the sun.

Serum 25-hydroxyvitamin D $\quad$ [25(OH)D] concentrations are much lower in CA than in NE. As
Table 3 shows [6-19], mean serum 25(OH)D concentrations range from 4 to $23 \mathrm{ng} / \mathrm{ml}$ in $\mathrm{CA}$ and from 19 to $32 \mathrm{ng} / \mathrm{ml}$ in NE. (To convert $\mathrm{ng} / \mathrm{ml}$ to $\mathrm{nmol} / \mathrm{L}$, divide by 2.5.) Few papers were found regarding serum $25(\mathrm{OH}) \mathrm{D}$ concentrations in $\mathrm{CA}$, offering further evidence that little concern has been given to vitamin $D$ in that region. 
Table 3. Representative serum 25(OH)D concentrations for various countries

\begin{tabular}{|c|c|c|c|c|c|}
\hline Country & $25(\mathrm{OH}) \mathrm{D}(\mathrm{ng} / \mathrm{ml})$ & Population & Date & Age (yrs) & Reference \\
\hline Afghanistan & $\begin{array}{l}\text { M, } 7(3-11) \\
F, 4(3-13)\end{array}$ & $\begin{array}{l}\text { Socioeconomically deprived } \\
\text { children }\end{array}$ & Jan. 2005 & $0.5-1$ & [6] \\
\hline Afghanistan & $\begin{array}{l}\text { M, } 5(2-17) \\
\text { F, } 5(2-25)\end{array}$ & $\begin{array}{l}\text { Socioeconomically deprived } \\
\text { children }\end{array}$ & Jan. 2005 & $1-4$ & [6] \\
\hline Afghanistan & 10.5 & 82 Immigrants in Norway & 2010 & & [7] \\
\hline Kazakhstan & $24(16-34)$ & HIV patients & & & [8] \\
\hline & $18 \pm 10$ & 126 Children & $2009-10$ & $0.5-3$ & [9] \\
\hline Kyrgyzstan & $21 \pm 7$ & 110 Healthy children, autumn & & $13-18$ & [10] \\
\hline Mongolia & $8 \pm 4$ & 420 Mothers of schoolchildren & $\begin{array}{l}\text { March- } \\
\text { April } 2009\end{array}$ & $35 \pm 5$ & [11] \\
\hline Mongolia & $\begin{array}{l}\text { Win, } 8 \text { (5-11); } \\
\text { sum, } 23(15-33)\end{array}$ & Healthy men, women & $\begin{array}{l}2011- \\
2013\end{array}$ & $20-58$ & [12] \\
\hline Mongolia & $\begin{array}{l}\text { Win, } 11 \pm 4 ; \text { sum, } \\
19 \pm 7\end{array}$ & 390 Pregnant women, win, sum & $\begin{array}{l}2011- \\
2013\end{array}$ & $16-40+$ & [13] \\
\hline Tajikistan & No data & & & & \\
\hline Turkmenistan & No data & & & & \\
\hline Uzbekistan & $79 \%<12$ & 474 Infants & $\begin{array}{l}\text { Feb.-May } \\
2004\end{array}$ & 5-61 wks & [14] \\
\hline Finland & 23 & 2822 Men and women & & $45-74$ & [15] \\
\hline Norway & $19 \pm 7$ & 6112 & $2006-08$ & $20+$ & [16] \\
\hline Norway & $26 \pm 7$ & 4465 & $2012-14$ & $40-69$ & [17] \\
\hline Sweden & $\begin{array}{l}\mathrm{T} 1,26 \pm 10 \\
\mathrm{~T} 3,30 \pm 14\end{array}$ & 1810 Pregnant women & $2013-14$ & & [18] \\
\hline Sweden & $32 \pm 10$ & $\begin{array}{l}44 \text { Patients with back pain, } 44 \\
\text { controls, general population }\end{array}$ & 2012 & $55 \pm 15$ & [19] \\
\hline
\end{tabular}

25(OH)D, 25-hydroxyvitamin D; F, female; HIV, human immunodeficiency virus; M, male; sum, summer; T1, first trimester; $\mathrm{T} 3$, third trimester; win, winter

I now turn to evidence that vitamin $\mathrm{D}$ has significant benefits in reducing risk of adverse health outcomes.

\section{Cancer}

Geographical ecological studies report inverse relationships between solar ultraviolet-B (UVB) doses and incidence/mortality rates for about 20 cancers [20]. In Nordic countries, outdoor occupation with UVB exposure is significantly inversely correlated with incidence of 14 cancers [21]. Observational studies show inverse correlations between serum 25(OH)D concentrations and colorectal cancer [22]. Pooled studies involving women, many of whom were taking high doses of vitamin $D$, indicate inverse correlations between serum $25(\mathrm{OH}) \mathrm{D}$ concentration and both all-cancer incidence [23] and breast cancer incidence [24]. Recently the results of a large randomized controlled trial (RCT), VITamin $D$ and OmegA-3 TriaL (VITAL), were released regarding supplementation with $2000 \mathrm{IU} / \mathrm{d}$ of vitamin $\mathrm{D}_{3}$ and all-cancer incidence. Although the results for the entire 25,000 participants were not significant, they were for some subgroups. For participants with body mass index $<25 \mathrm{~kg} / \mathrm{m}^{2}$ of body surface area, the hazard ratio $(\mathrm{HR})$ was $0.76(95 \%$ Confidence Interval [Cl], 0.76 to 0.90 ); for blacks, $\mathrm{HR}=0.77$ $(95 \% \mathrm{Cl}, 0.59$ to 1.01$)$; and when results during the first year were omitted, the HR for all-cancer death was $0.79(95 \% \mathrm{Cl}, 0.63$ to 0.99$)$. A recent letter to the editor made the case for accepting secondary analyses such as these [5]. 


\section{Central Asian Journal of Medical Hypotheses and Ethics| \\ 2020; Vol 1}

\section{Diabetes mellitus type 2}

Observational studies show that higher serum $25(\mathrm{OH}) \mathrm{D}$ concentration is associated with reduced risk of developing type 2 diabetes mellitus (T2DM). A meta-analysis reported a relative risk of 0.66 (95\% $\mathrm{Cl}, 0.61$ to 0.73 ) for T2DM with respect to high versus low $25(\mathrm{OH}) \mathrm{D}$ concentration [25]. A recent RCT in which participants were given $4000 \mathrm{lU} / \mathrm{d}$ of vitamin $\mathrm{D}_{3}$ in the treatment arm reported that several subgroups had significant (or nearly so) reductions in progression to T2DM: body mass index $<30, \mathrm{HR}$ $=0.71(95 \% \mathrm{Cl}, 0.53$ to 0.95); non-Hispanics, $\mathrm{HR}=$ $0.86(95 \% \mathrm{Cl}, 0.72$ to 1.02$)$; males, $\mathrm{HR}=0.82(95 \%$ $\mathrm{Cl}, 0.66$ to 1.01); people $>60.9 \mathrm{yrs}, \mathrm{HR}=0.80(95 \%$ $\mathrm{Cl}, 0.64$ to 1.01); people at or above $37^{\circ} \mathrm{N}$ latitude, $0.85(95 \% \mathrm{Cl}, 0.70$ to 1.03$)$; and people with no calcium supplements intake, $\mathrm{HR}=0.81$ (0.66 to 0.98) [26]. A recent commentary in Nature argued that $p=0.05$ is an arbitrary cutoff between significant and not significant [27]. Thus, the $95 \% \mathrm{Cl}$ values slightly larger than 1.00 should be considered to demonstrate significance even though the $p$-value is slightly larger than 0.05 .

\section{Ischemic heart disease}

Good observational evidence indicates that serum $25(\mathrm{OH}) \mathrm{D}$ concentration is inversely correlated with IHD incidence, but no evidence has come from vitamin D supplementation studies. A 2012 metaanalysis reported that the relative risk of IHD doubled when baseline 25(OH)D concentration decreased from 20 to $6 \mathrm{ng} / \mathrm{ml}$ [28]. The most recent vitamin $\mathrm{D} R C T$, the VITAL study, showed no significant benefit for IHD with $2000 \mathrm{IU} / \mathrm{d}$ of vitamin $\mathrm{D}_{3}$ supplementation [29]. However, the mean baseline 25(OH)D concentration for participants who provided data was near $31 \mathrm{ng} / \mathrm{ml}$, with few having 25(OH)D concentration below $15 \mathrm{ng} / \mathrm{ml}$. In addition, participants in the control arm were permitted to take up to $600 \mathrm{lU} / \mathrm{d}(800 \mathrm{lU} / \mathrm{d}$ if older than $70 \mathrm{yrs}$ ) of vitamin $\mathrm{D}_{3}$.

\section{Stroke}

In a meta-analysis of 19 studies, a significantly increased risk of stroke for low $25(\mathrm{OH}) \mathrm{D}$ concentration was evident. The risk ratio for stroke incidence for low versus high $25(\mathrm{OH}) \mathrm{D}$ from 16 prospective studies was $1.32(95 \% \mathrm{Cl}, 1.19$ to 1.46$)$, whereas that from three case-control studies was $6.6(95 \% \mathrm{Cl}, 1.2$ to 37.0$)$ [30]. The total risk ratio was
$1.60(95 \% \mathrm{Cl}, 1.33$ to 1.92$)$. However, vitamin D supplementation has not been shown to reduce risk of stroke [31]. But stroke often occurs for people with very low $25(\mathrm{OH}) \mathrm{D}$ concentration, and such people are generally not included in vitamin $D$ RCTs. In addition, hypertension is an important risk factor for stroke [32], and an open-label study reported that participants with hypertension who took $4000 \mathrm{lU} / \mathrm{d}$ of vitamin $\mathrm{D}$ reduced systolic and diastolic blood pressure by $10-15 \mathrm{mmHg}$, to below the threshold for hypertension [33].

\section{Chronic obstructive pulmonary disease}

A meta-analysis reported that vitamin D supplementation can substantially reduce the rate of moderate/severe chronic obstructive pulmonary disease exacerbations for people with baseline $25(\mathrm{OH}) \mathrm{D}$ concentration $<10 \mathrm{ng} / \mathrm{ml}$ (adjusted incidence rate ratio $=0.55[95 \% \mathrm{Cl}, 0.36$ to 0.84$]$ ) but not for those with higher baseline concentrations [34].

\section{Cirrhosis of the liver}

"Vitamin D deficiency in cirrhosis relates to liver dysfunction rather than aetiology, with lower levels of vitamin $\mathrm{D}$ in alcoholic cirrhosis than in primary biliary cirrhosis" [35]. However, vitamin D supplementation improves the probability of achieving a sustained immune response after antiviral treatment for people with $25(\mathrm{OH}) \mathrm{D}$ concentration $<20 \mathrm{ng} / \mathrm{ml}$ [36]. A review of vitamin D's antimicrobial properties appears in a review by Youssef and colleagues [37].

\section{Chronic kidney disease}

A meta-analysis of 16 studies involving 17,053 chronic kidney disease (CKD) patients with 7517 incident deaths indicated that a $10-\mathrm{ng} / \mathrm{ml}$ increment in $25(\mathrm{OH}) \mathrm{D}$ was associated with a $21 \%$ reduction in overall mortality (RR $=0.79[95 \% \mathrm{Cl}, 0.70$ to 0.87$])$ for people with baseline $25(\mathrm{OH}) \mathrm{D}$ concentration below about $35 \mathrm{ng} / \mathrm{ml}$ [38]. Another meta-analysis showed that the reduction in all-cause mortality rate was higher for CKD patients not receiving dialysis (four studies; risk ratio $=0.53[95 \% \mathrm{Cl}, 0.32$ to 0.87$]$ ) than those receiving dialysis (16 studies) (risk ratio $=0.66[95 \% \mathrm{Cl}, 0.57$ to 0.75]) [39]. However, that paper also reported that vitamin D RCTs have not shown a significant benefit in reducing all-cause or 


\section{Central Asian Journal of Medical Hypotheses and Ethics| \\ 2020; Vol 1}

cardiovascular disease mortality rates for CKD patients.

\section{Acute respiratory tract infections}

Acute respiratory tract infections (ARIs) are most common in winter, when UVB doses-and thus vitamin D status-are low [40]. A meta-analysis of vitamin $D$ RCTs for ARls showed that supplementing with vitamin $D$ reduced the risk of ARIs, with greatest impact on people with $25(\mathrm{OH}) \mathrm{D}$ concentrations $<10 \mathrm{ng} / \mathrm{ml}$ (Adjusted Odds Ratio = 0.30 [95\% Cl, 0.17 to 0.53$])$ [41].

\section{Pregnancy}

Vitamin D status during pregnancy and lactation is an important consideration. The developing fetus relies on genes to guide somatic development. The hormonal metabolite of vitamin $\mathrm{D}, 1,25(\mathrm{OH})_{2} \mathrm{D}$, affects the expression of many genes through vitamin D receptors coupled to chromosomes [42]. One important effect of vitamin $D$ during pregnancy is to reduce the risk of preterm delivery. In an openlabel study in South Carolina, women had their $25(\mathrm{OH}) \mathrm{D}$ concentration measured near the 12th week of pregnancy and were then given bottles of 5000-IU vitamin $D$ and counseled on how to achieve concentrations of $>40 \mathrm{ng} / \mathrm{ml}$ [43]. Those women who achieved $>40 \mathrm{ng} / \mathrm{ml}$ had $61 \%$ reduced risk of preterm delivery in comparison with those with $25(\mathrm{OH}) \mathrm{D}<20 \mathrm{ng} / \mathrm{ml}$ (relative risk $=0.41[95 \% \mathrm{Cl}$, 0.24 to 0.72$]$ ). Higher vitamin $D$ status has also been associated with reduced risk of preeclampsia [44] and gestational diabetes [45] as well as reduced risk of offspring with rickets [46].

\section{All-cause mortality rate}

On the basis of the understanding of $25(\mathrm{OH}) \mathrm{D}$ concentration-health outcome relations, it was estimated in 2011 that if continental population mean $25(\mathrm{OH}) \mathrm{D}$ concentrations were raised from 22 to $44 \mathrm{ng} / \mathrm{ml}$, mortality rates would decrease by $8 \%$ (for countries with low life expectancies) to $17 \%$ (for countries with high life expectancies). That decrease translates to about 2 years of increased life expectancy [47]. A meta-analysis of 32 observational studies reported that all-cause mortality rates were reduced by about $30 \pm 20 \%$ when $25(\mathrm{OH}) \mathrm{D}$ was increased from 20 to $40 \mathrm{ng} / \mathrm{ml}$ [48].

\section{CONCLUSION}

Several steps can be taken to improve the vitamin $D$ status in CA. One is to consider fortifying commonly consumed foods such as dairy, flour, and oil foodstuffs [49]. The goal of food fortification should be to have most people achieve a $25(\mathrm{OH}) \mathrm{D}$ concentration of at least $20 \mathrm{ng} / \mathrm{ml}$. The second step would be to consider making vitamin $D$ supplements more readily available and to publicize the need for vitamin $D$, especially for various subgroups of the population. The goal should be to have supplement takers achieve concentrations of at least $30 \mathrm{ng} / \mathrm{ml}$, if not $40 \mathrm{ng} / \mathrm{ml}$ [50]. The third step would be to conduct observational studies and clinical trials regarding the health benefits of vitamin $D$ in $C A$, which may differ from what has been found in other countries.

\section{FUNDING}

The author is a recipient of research funding from Bio-Tech Pharmacal, Inc. (Fayetteville, AR, USA).

\section{AUTHOR CONTRIBUTIONS}

Substantial contributions to the conception or design of the work, acquisition, analysis, and interpretation of data - WBG. Drafting and revising the manuscript -WBG. Final approval of the version to be published - WBG. Agreement to be accountable for all aspects of the work in ensuring that questions related to the accuracy or integrity of any part of the work are appropriately investigated and resolved - WBG.

\section{CONFLICTS OF INTEREST \\ None}

\section{DISCLAIMER}

No part of the manuscript has been submitted simultaneously or published elsewhere. 


\section{Central Asian Journal of Medical Hypotheses and Ethics| \\ 2020; Vol 1}

\section{REFERENCES}

1. Holick MF. Vitamin D deficiency. N Engl J Med 2007;357(3):266-281.

2. Pludowski P, Holick MF, Pilz S, Wagner CL, Hollis BW, Grant WB, et al. Vitamin D effects on musculoskeletal health, immunity, autoimmunity, cardiovascular disease, cancer, fertility, pregnancy, dementia and mortality-a review of recent evidence. Autoimmun Rev 2013;12(10):976-989.

3. WHO. World Health Statistics 2018: Monitoring health for the SDGs, sustainable development goals. Geneva: World Health Organization; 20182018.

4. WHO. World Health Statistics 2016: Annex B: Tables of health statistics by country, WHO region and globally. Geneva: World Health Organization; 2016. Report No.: 9789241565264 Contract No.: 13 September 2019.

5. Grant WB, Boucher BJ. Why Secondary Analyses in Vitamin D Clinical Trials Are Important and How to Improve Vitamin D Clinical Trial Outcome Analyses-A Comment on "Extra-Skeletal Effects of Vitamin D, Nutrients 2019, 11, 1460". Nutrients 2019;11(9): pii: E2182.

6. Manaseki-Holland S, Zulf Mughal M, Bhutta Z, Qasem Shams M. Vitamin D status of socioeconomically deprived children in Kabul, Afghanistan. Int J Vitam Nutr Res 2008;78(1):16-20.

7. Eggemoen AR, Knutsen KV, Dalen I, Jenum AK. Vitamin D status in recently arrived immigrants from Africa and Asia: a cross-sectional study from Norway of children, adolescents and adults. BMJ Open 2013;3(10):e003293.

8. Nugmanova Z, Patel N, Akhmetova GM, Kurmangalieva GS, Abdumananova MK, Akanov AA, et al. Relationship between vitamin D and human immunodeficiency virus (HIV) viral load among HIV-infected patients in Kazakhstan. J Infect Dev Ctries 2015;9(11):1277-1283.

9. Hearst MO, Himes JH, Spoon F, Johnson DE, Kroupina M, Syzdykova A, et al. Growth, nutritional, and developmental status of young children living in orphanages in Kazakhstan. Infant Ment Health J 2014;35(2):94-101.

10. Amanzholkyzy A, Nurgalieva RE, Dosimov AZ, Stankevicius E, Kaldybaeva AT. Ethnic Manifestations of Gene Polymorphisms of Vitamin D Receptor (VDR) in Adolescents of Western Kazakhstan Region. J Natl Med Assoc 2018;110(1):78-83.

11. Ganmaa D, Holick MF, Rich-Edwards JW, Frazier LA, Davaalkham D, Ninjin B, et al. Vitamin D deficiency in reproductive age Mongolian women: a cross sectional study. J Steroid Biochem Mol Biol 2014;139:1-6.

12. Bromage S, Rich-Edwards JW, Tselmen D, Baylin A, Houghton LA, Baasanjav N, et al. Seasonal Epidemiology of Serum 25-Hydroxyvitamin D Concentrations among Healthy Adults Living in Rural and Urban Areas in Mongolia. Nutrients 2016;8(10).pii: E592.

13. Bromage S, Enkhmaa D, Baatar T, Garmaa G, Bradwin G, Yondonsambuu B, et al. Comparison of seasonal serum 25-hydroxyvitamin $\mathrm{D}$ concentrations among pregnant women in Mongolia and Boston. J Steroid Biochem Mol Biol 2019;193:105427.

14. Güngör D, BiÇer I, Rodrigues Pereira R, Rasulov AS, Rachimov AU, Mavlyanov S, et al. Prevalence of vitamin D deficiency in Samarkand, Uzbekistan. J Nutr Environ Med 2008;17(4):223-231.

15. Miettinen ME, Kinnunen L, Leiviska J, Keinanen-Kiukaanniemi S, Korpi-Hyovalti E, Niskanen L, et al. Association of serum 25-hydroxyvitamin D with lifestyle factors and metabolic and cardiovascular disease markers: population-based cross-sectional study (FIN-D2D). PloS One 2014;9(7):e100235.

16. Sun YQ, Langhammer A, Skorpen F, Chen Y, Mai XM. Serum 25-hydroxyvitamin D level, chronic diseases and all-cause mortality in a population-based prospective cohort: the HUNT Study, Norway. BMJ Open 2017;7(6):e017256.

17. Petrenya N, Lamberg-Allardt C, Melhus M, Broderstad AR, Brustad M. Vitamin D status in a multiethnic population of northern Norway: the SAMINOR 2 Clinical Survey. Public Health Nutr 2019:1-15. [Epub ahead of print]. 


\section{Central Asian Journal of Medical Hypotheses and Ethics| \\ 2020; Vol 1}

18. Barebring L, Bullarbo M, Glantz A, Hulthen L, Ellis J, Jagner A, et al. Trajectory of vitamin D status during pregnancy in relation to neonatal birth size and fetal survival: a prospective cohort study. BMC Pregnancy Childbirth 2018;18(1):51.

19. Thorneby A, Nordeman LM, Johanson EH. No association between level of vitamin D and chronic low back pain in Swedish primary care: a cross-sectional case-control study. Scand J Prim Health Care 2016;34(2):196-204.

20. Moukayed M, Grant WB. Molecular link between vitamin D and cancer prevention. Nutrients 2013;5(10):3993-4021.

21. Grant WB. Role of solar UVB irradiance and smoking in cancer as inferred from cancer incidence rates by occupation in Nordic countries. Dermatoendocrinol 2012;4(2):203-211.

22. McCullough ML, Zoltick ES, Weinstein SJ, Fedirko V, Wang M, Cook NR, et al. Circulating Vitamin D and Colorectal Cancer Risk: An International Pooling Project of 17 Cohorts. J Natl Cancer Inst 2019;111(2):158-169.

23. McDonnell SL, Baggerly C, French CB, Baggerly LL, Garland CF, Gorham ED, et al. Serum 25Hydroxyvitamin D Concentrations $>/=40 \mathrm{ng} / \mathrm{ml}$ Are Associated with $>65 \%$ Lower Cancer Risk: Pooled Analysis of Randomized Trial and Prospective Cohort Study. PloS One 2016;11(4):e0152441.

24. McDonnell SL, Baggerly CA, French CB, Baggerly LL, Garland CF, Gorham ED, et al. Breast cancer risk markedly lower with serum 25 -hydroxyvitamin $D$ concentrations $>/=60 \mathrm{vs}<20 \mathrm{ng} / \mathrm{ml}(150 \mathrm{vs} 50 \mathrm{nmol} / \mathrm{L}$ ): Pooled analysis of two randomized trials and a prospective cohort. PloS One 2018;13(6):e0199265.

25. Ekmekcioglu C, Haluza D, Kundi M. 25-Hydroxyvitamin D Status and Risk for Colorectal Cancer and Type 2 Diabetes Mellitus: A Systematic Review and Meta-Analysis of Epidemiological Studies. Int J Environ Res Public Health 2017;14(2). pii: E127.

26. Pittas AG, Dawson-Hughes B, Sheehan P, Ware JH, Knowler WC, Aroda VR, et al. Vitamin D Supplementation and Prevention of Type 2 Diabetes. N Engl J Med 2019;381(6):520-530.

27. Amrhein V, Greenland S, McShane B. Scientists rise up against statistical significance. Nature 2019;567(7748):305-307.

28. Wang L, Song Y, Manson JE, Pilz S, Marz W, Michaelsson K, et al. Circulating 25-hydroxy-vitamin D and risk of cardiovascular disease: a meta-analysis of prospective studies. Circ Cardiovasc Qual Outcomes 2012;5(6):819-829.

29. Manson JE, Cook NR, Lee IM, Christen W, Bassuk SS, Mora S, et al. Vitamin D Supplements and Prevention of Cancer and Cardiovascular Disease. N Engl J Med 2019;380(1):33-44.

30. Zhou R, Wang M, Huang H, Li W, Hu Y, Wu T. Lower Vitamin D Status Is Associated with an Increased Risk of Ischemic Stroke: A Systematic Review and Meta-Analysis. Nutrients 2018;10(3). pii: E277.

31. Barbarawi M, Kheiri B, Zayed Y, et al. Vitamin D Supplementation and Cardiovascular Disease Risks in More Than 83000 Individuals in 21 Randomized Clinical Trials: A Meta-analysis. JAMA Cardiol 2019. [Epub ahead of print].

32. Turin TC, Okamura T, Afzal AR, Rumana N, Watanabe M, Higashiyama A, et al. Hypertension and lifetime risk of stroke. J Hypertens 2016;34(1):116-122.

33. Mirhosseini N, Vatanparast H, Kimball SM. The Association between Serum 25(OH)D Status and Blood Pressure in Participants of a Community-Based Program Taking Vitamin D Supplements. Nutrients 2017;9(11). pii: E1244.

34. Jolliffe DA, Ganmaa D, Wejse C, Raqib R, Haq MA, Salahuddin N, et al. Adjunctive vitamin D in tuberculosis treatment: meta-analysis of individual participant data. Eur Respir J 2019;53(3). pii: 1802003.

35. Malham M, Jorgensen SP, Ott P, Agnholt J, Vilstrup H, Borre M, et al. Vitamin D deficiency in cirrhosis relates to liver dysfunction rather than aetiology. World J Gastroenterol 2011;17(7):922-925.

36. Bitetto D, Fabris C, Falleti E, Fornasiere E, Fumolo E, Fontanini E, et al. Vitamin D and the risk of acute allograft rejection following human liver transplantation. Liver Int 2010;30(3):417-444.

37. Youssef DA, Miller CW, El-Abbassi AM, Cutchins DC, Cutchins C, Grant WB, et al. Antimicrobial implications of vitamin D. Dermatoendocrinol 2011;3(4):220-229. 


\section{Central Asian Journal of Medical Hypotheses and Ethics| \\ 2020; Vol 1}

38. Jayedi A, Soltani S, Shab-Bidar S. Vitamin D status and all-cause mortality in patients with chronic kidney disease: A systematic review and dose-response meta-analysis. J Clin Endocrinol Metab 2017. [Epub ahead of print].

39. Lu RJ, Zhu SM, Tang FL, Zhu XS, Fan ZD, Wang GL, et al. Effects of vitamin D or its analogues on the mortality of patients with chronic kidney disease: an updated systematic review and meta-analysis. Eur $\mathrm{J}$ Clin Nutr 2017;71(6):683-693.

40. Cannell JJ, Vieth R, Umhau JC, Holick MF, Grant WB, Madronich S, et al. Epidemic influenza and vitamin D. Epidemiol Infect 2006;134(6):1129-1140.

41. Martineau AR, Jolliffe DA, Hooper RL, Greenberg L, Aloia JF, Bergman P, et al. Vitamin D

supplementation to prevent acute respiratory tract infections: systematic review and meta-analysis of individual participant data. BMJ 2017;356:i6583.

42. Pike JW, Christakos S. Biology and Mechanisms of Action of the Vitamin D Hormone. Endocrinol Metab Clin North Am 2017;46(4):815-843.

43. McDonnell SL, Baggerly KA, Baggerly CA, Aliano JL, French CB, Baggerly LL, et al. Maternal $25(\mathrm{OH}) \mathrm{D}$ concentrations $>/=40 \mathrm{ng} / \mathrm{mL}$ associated with $60 \%$ lower preterm birth risk among general obstetrical patients at an urban medical center. PloS One 2017;12(7):e0180483.

44. Ali AM, Alobaid A, Malhis TN, Khattab AF. Effect of vitamin D3 supplementation in pregnancy on risk of pre-eclampsia - Randomized controlled trial. Clin Nutr 2019;38(2):557-563.

45. Zhang Y, Gong Y, Xue H, Xiong J, Cheng G. Vitamin D and gestational diabetes mellitus: a systematic review based on data free of Hawthorne effect. BJOG 2018;125(7):784-793.

46. Holick MF. Resurrection of vitamin D deficiency and rickets. J Clin Invest 2006;116(8):2062-2072.

47. Grant WB. An estimate of the global reduction in mortality rates through doubling vitamin $\mathrm{D}$ levels. Eur J Clin Nutr 2011;65(9):1016-1026.

48. Garland CF, Kim JJ, Mohr SB, Gorham ED, Grant WB, Giovannucci EL, et al. Meta-analysis of AllCause Mortality According to Serum 25-Hydroxyvitamin D. Am J Public Health 2014;104(8):e43-e50.

49. Pilz S, Marz W, Cashman KD, Kiely ME, Whiting SJ, Holick MF, et al. Rationale and Plan for Vitamin D Food Fortification: A Review and Guidance Paper. Front Endocrinol (Lausanne) 2018;9:373.

50. Pludowski P, Holick MF, Grant WB, Konstantynowicz J, Mascarenhas MR, Haq A, et al. Vitamin D supplementation guidelines. J Steroid Biochem Mol Biol 2018;175:125-135.

\section{Түйіндеме}

\section{Орталық Азия мен Солтүстік Еуропада Д дәруменінің рөлін салыстыру}

Соңғы екі онжылдықта Д дәруменінің рөлін түсіну кеңейіп, қазіргі кезде жедел респираторлық инфекциялар, аутоиммунды аурулар, қатерлі ісік, жүрек-қантамыр аурулары, қант диабеті, неврологиялық аурулар, жүктілік пен босанудың қолайсыздығының қаупін азайту сияқты көптеген әсерлерді қамтиды. Қоғамдық денсаулықтың оңтайлы деңгейін қамтамасыз етудегі D дәруменінің рөлі Батыстың дамыған елдерінде жақсы белгілі, бірақ ол Орталық Азия елдерінде аз белгілі. Бұл әдебиетке шолу барысында Орта Азия мен Солтүстік Еуропадағы D дәруменіне байланысты ақпараттың қаныққтылығы салыстырылады. Талдау сонымен қатар D дәруменінің оң әсері туралы мәліметтер мен Орталық Азия елдері үшін ұсыныстарды қамтиды.

Түйін сөздер: Д дәрумені, Орталық Азия, Еуропа, Гипотеза

Дәйексөз үшін: Грант В. Б. Орталық Азия мен Солтүстік Еуропада Д дәруменінің рөлін салыстыру. Медициналық гипотеза мен этиканың Орта Азиялық журналы. - 2020. - №1 (1). Б. 33 - 42 https://doi.org/10.47316/cajmhe.2020.1.1.05

\section{Сравнительный анализ статуса витамина D в странах Центральной Азии и Северной Европы}

\section{Резюме}

В течение двух последних десятилетий было расширено понимание роли витамина D для организма человека. Помимо эфффектов, оказываемых на скелет, были выявлены такие эфффекты как снижение риска развития острых инфекционных заболеваний дыхательных 


\section{Central Asian Journal of Medical Hypotheses and Ethics| \\ 2020; Vol 1}

путей, аутоиммунных заболеваний, рака, сердечно-сосудистых заболеваний, сахарного диабета, неврологических заболеваний, а также снижение риска неблагоприятных исходов беременности и родов. Сегодня в развитых странах Запада хорошо изучена роль витамина D как элемента для обеспечения оптимального уровня общественного здоровья, однако в странах Центральной Азии витамин D изучен не так хорошо. В данном литературном обзоре сравнивается статус витамина D в странах Центральной Азии и Северной Европы. Анализ также содержит данные о положительных эффектах витамина D и рекомендации для стран Центральной Азии.

Ключевые слова: Витамин D, Центральная Азия, Европа, Гипотеза

Для цитирования: Грант В. Б. Сравнительный анализ статуса витамина D в странах Центральной Азии и Северной Европы. Центральноазиатский журнал медицинских гипотез и этики. - 2020. - №1(1). - С. 33 - 42. https://doi.org/10.47316/cajmhe.2020.1.1.05 